\title{
Brazil nuts: determination of natural elements and aflatoxin
}

\author{
Maristela MARTINS ${ }^{1}$, Ariane Mendonça PACHECO ${ }^{1 *}$, Ana Cyra Santos LUCAS ${ }^{1}$, Avacir Casanova \\ ANDRELLO², Carlos Roberto APPOLONI², Jose Junior Mendonça XAVIER ${ }^{3}$
}

\section{ABSTRACT}

A study was carried out to evaluate the association of levels of radioactivity, selenium and aflatoxin in shelled Brazil nuts, which were classified in different sizes, for export. The selenium determinations were performed by inductively coupled plasma optical emission spectrometry (LOQ $\left.=3.0 \mu \mathrm{g} \mathrm{g}^{-1}\right)$, and aflatoxins were detected by Liquid chromatography-mass spectrometry $\left(\mathrm{LOQ}=0.85 \mu \mathrm{g} \mathrm{kg}^{-1}\right)$, recovery rates were between 92 and $100 \%$. Radioactivity was measured by high-resolution gamma spectrometry. The selenium mean concentration was $(22.7 \pm 7.4) \mu \mathrm{g} \mathrm{g}^{-1}$. $(\mathrm{n}=30)$. Mean activities determined for the following radium isotopes were: $15.77 \mathrm{~Bq} \mathrm{~kg}^{-1}$ for ${ }^{224} \mathrm{Ra}, 104.8 \mathrm{~Bq} \mathrm{~kg}^{-1}$ for ${ }^{226} \mathrm{Ra}$ and $99.48 \mathrm{~Bq} \mathrm{~kg}^{-1}$ for ${ }^{228} \mathrm{Ra}$. For ${ }^{226} \mathrm{Ra}$, the levels did not vary significantly with nut sizes, although such differences were observed for ${ }^{224} \mathrm{Ra}$ and ${ }^{228} \mathrm{Ra}$. There was no statistically significant association between the level of selenium and the activity of radionuclides, however, there was correlation between the radionuclides. Aflatoxins above the quantification limit were not found.

KEYWORDS: radioactivity; selenium; Bertholletia excelsa.

\section{Castanha do Brasil: determinação de elementos naturais e aflatoxinas}

\section{RESUMO}

Um estudo foi realizado para avaliar a associação dos níveis de radioatividade, selênio e aflatoxinas em castanha-do-Brasil descascada, que foram classificadas em diferentes tamanhos, para exportação. As determinaçóes de selênio foram realizadas por espectrometria de emissão óptica com plasma indutivamente acoplado ( $\mathrm{LOQ}=3,0 \mu \mathrm{g} \mathrm{kg}^{-1}$ ) e aflatoxinas foram detectadas por LC-MSMS (LOQ=0,85 $\mu \mathrm{g} \mathrm{kg}^{-1}$ ), as taxas de recuperação ficaram entre 92 e $100 \%$. A radioatividade foi medida por espectrometria gama de alta resolução. A concentração média de selênio foi de $(22,7 \pm 7,4) \mu \mathrm{g} \mathrm{g}^{-1}$. ( $\left.\mathrm{n}=30\right)$. A atividade média determinada para os radioisótopos foram: $15,77 \mathrm{~Bq} \mathrm{~kg}^{-1}$ para o ${ }^{224} \mathrm{Ra}, 104,8 \mathrm{~Bq} \mathrm{~kg}^{-1}$ para ${ }^{226} \mathrm{Ra}$ e $99,48 \mathrm{~Bq} \mathrm{~kg}{ }^{-1}$ para ${ }^{228} \mathrm{Ra}$. Para ${ }^{226} \mathrm{Ra}$, os níveis não variaram significativamente com o tamanho das nozes, embora tais diferenças foram observadas para ${ }^{224} \mathrm{Ra}$ e ${ }^{228} \mathrm{Ra}$. Não houve associação estatisticamente significativa entre o nível de selênio e a atividade de radionuclídeos, no entanto, houve correlação entre os radionuclídeos. Não foi encontrado aflatoxinas acima do limite de quantifcação.

PALAVRAS-CHAVE: radioatividade, selênio, bertholletia excelsa.

1 Faculty of Pharmaceutical Sciences, Federal University of Amazonas, Manaus, Amazonas, Brazil, 69010-330

2 Department of Physical, State University of Londrina, Londrina, Paraná, Brazil, 86051-990.

${ }^{3}$ Applied Biosystems of Brazil, São Paulo, Brazil, 04311-000

* To whom correspondence should be addressed. Phone/Fax: + 55 (92) 3305 5000. E-mail: arianepacheco@hotmail.com 
Brazil nuts: determination of natural elements and aflatoxin

\section{INTRODUCTION}

The contamination by fungi and their metabolites in food has been focused on the food science to identify risks and prevent diseases. However, the natural properties of some foods, such as radioactivity and their chemical compositions, have been assessed as being active in themselves, but not deeply studied in tree nuts, for example.

The Brazil nut (Bertholletia excelsa HBK) is well-known as a relevant food with nutritional properties, such as a high protein content (15-20\%) and sulfur amino acids, $60-70 \%$ lipids (Essential fatty acids), vitamin E (Chunhieng et al. 2008) and antioxidant properties due to its selenium content (Ryan et al. 2006).

Selenium (Se) is an essential micronutrient that, once incorporated into selenoproteins, performs important functions in the human body, participating in antioxidant defense, in the immune system and in the regulation of thyroid function (Rayman 2000). Glutathione peroxidase is a selenoprotein that acts as an antioxidant enzyme in plasma and is associated with slowing the aging process, boosting the immune system and protecting against heart disease and certain forms of cancer (Yang 2009). However, at doses above the recommended daily intake of $55 \mu \mathrm{g}$ per day, Se can be toxic (Yang 2009). Brazil nut trees absorb the natural element Se from soil (Parekh et al. 2008) as along with radionuclides, such as ${ }^{226} \mathrm{Ra}$ (Tagami and Uchida 2009).

The concentration of radioactive elements in Brazil nuts can reach quantities up to 1000 times greater than in other foods (Gabay and Sax 1969). Due to their high concentration of radionuclides, studies report that Brazil nuts are radioactive (Turner et al. 1958; Smith 1971). The occurrence of cancer is among the risks associated with the ingestion of radioactive foods, and monitoring is a form of health protection (Irigaray et al. 2007; Celik 2008).

The Brazil nut is native to the Amazon region and is economically important. It is collected in indigenous regions and in small communities during the rainy season, and transported to processing plants, to undergo treatment involving the following stages: sorting, drying, breaking and sorting by size. The initial stage of manual/visual sorting is important to remove moldy and stained nuts, and precedes classification by size. At the end of the drying and cooling processes, the product is subjected to vacuum packaging and hot sealing (Figure 1) (Pacheco and Scussel 2009).

Besides the amount exported from Brazil - around 23.600 $t$ in 2008/2009 (MICD 2010) - Brazil nuts have been used in industrial products, such as biscuits, oil, sweets, cereals and bakery products (Souza and Menezes 2004). However, the export of Brazil nuts to Europe has suffered drastic reductions

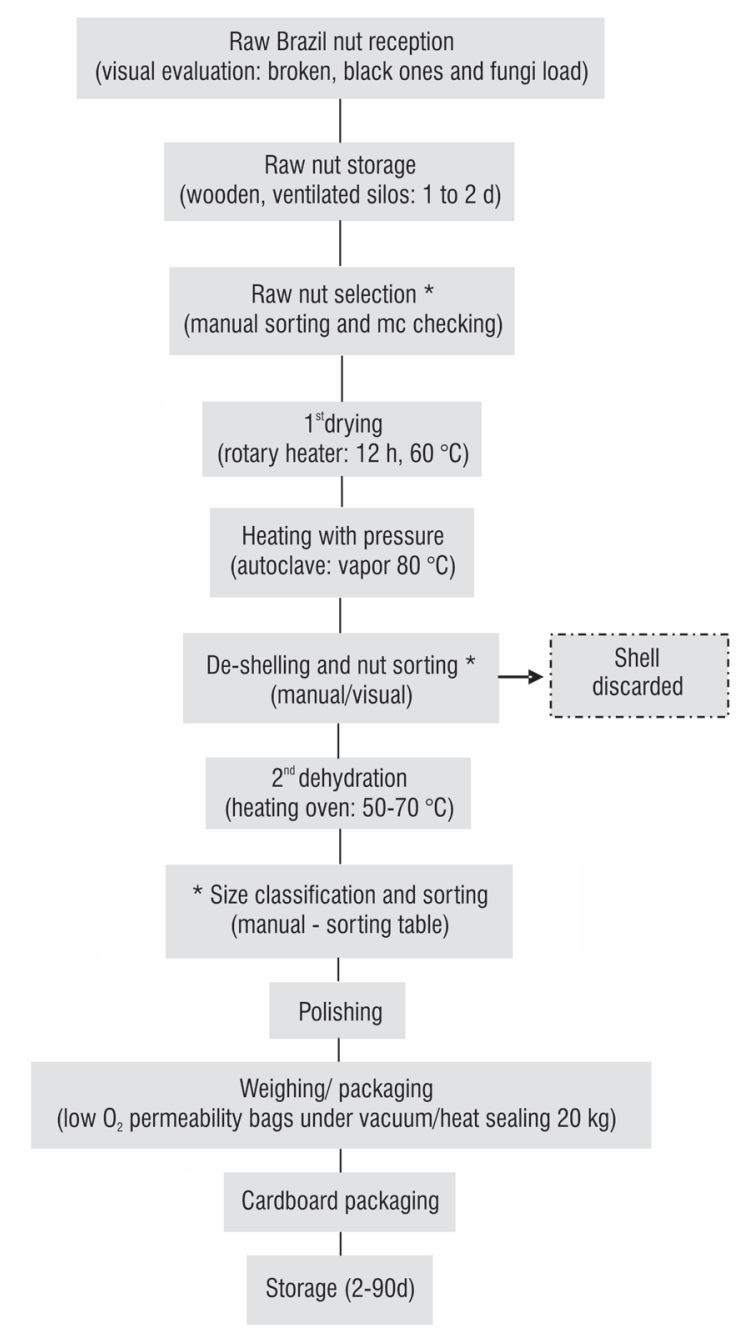

Figure 1 - General flowchart for processing of Brazil nuts including shelling and sorting steps $\left[{ }^{\star}\right]$ (Pacheco and Scussel 2009).

due to the presence of aflatoxins at concentrations exceeding those accepted by European legislation (EU 2003; $4 \mu \mathrm{g} \mathrm{kg}^{-1}$ ).

Aflatoxins are carcinogenic substances (IARC 1997) from the secondary metabolism of aflatoxigenic fungi. Brazil nuts and other tree nuts have been studied for their association with these fungi, as well as for levels of aflatoxin contamination (Scussel 2004). Brazil nut production occurs in environments with temperatures of $30-35^{\circ} \mathrm{C}$ and with high relative humidity (80-95\%). The environmental conditions in the Amazon region influence the level of water activity (Wa) and moisture in Brazil nuts and, favor aflatoxin production by some fungal strains (Johnsson et al. 2008).

Considering these aspects, the aim of this work was to evaluate the association of radioactive and selenium levels 
concerning the aflatoxins contamination in Brazil-nuts for export.

\section{MATERIALS AND METHODS}

\section{Reagents}

Reagents used in this study included: methanol, acetonitrile, benzene (HPLC grade, Carlo Erba, Rodano, Italy), ultrapure water (MilliQ system, Millipore, Billerica, USA) and ammonium acetate (analytical grade, Vetec, Rio de Janeiro, Brazil). Aflatoxin standards included: AFB1, AFB2, AFG1 and AFG2 (Sigma, Saint Louis, MO, USA).

\section{Instruments}

A liquid chromatograph was used (1100, Agilent, Santa Clara, USA) with a quaternary pump, degasser, autosampler and a $20 \mathrm{~mL}$ loop. Reverse phase columns studied included: three C18 (4.5 mm i.d., $150 \mathrm{~mm}$ length from Hichrom (Theale, UK) and of $250 \mathrm{~mm}$ length (5 and $10 \mathrm{~mm}$ i.d.)] from Phenomenex (Torrance, USA), and one C8 (4.6 mm i.d., $150 \mathrm{~mm}$ length) from Agilent (Santa Clara, USA). A liquid chromatograph coupled with tandem-mass spectrometer (LC-MS/MS) (Applied Biosystems MDS SCIEX, Foster City, USA) was equipped with an atmospheric pressure chemical ionization (APCI) and electrospray ionization (ESI) interfaces in positive modes as well as an infusion pump (Harvard Apparatus, Holliston, USA). An inductively coupled plasma optical emission spectrometer (Otima 2000, Perkin-Elmer, Toronto, Canada.), a mill (Romer, Union, USA), an industrial nut-cracker (CIEX, Manaus, Brazil), a HPGe detector (GEM-M-7080 PS, ORTEC, USA), a high voltage power supply (model ORTEC 659, USA), a pulse generator (model ORTEC 419, USA), a preamplifier and linear amplifier (ORTEC model 575, USA), an oscilloscope (model TDS tektronic 220), a multichannel plate (model ORTEC Trump-8K, USA) and a shield (ORTEC, model HPLDS1, USA).

\section{Sampling and preparation}

A total of 30 samples were collected from a batch of Brazil nuts for export from the 2009 harvest in a factory from the city of Manaus in the state of Amazonas, Brazil.

The sampling method used was that required by the European Union, (EU 2003). The samples were representatively collected from bags under vacuum/heat sealing of $20 \mathrm{~kg}$. Incremental samples were taken from the bags and homogenized. Final portions of $1 \mathrm{~kg}$ were packed and immediately sent to the laboratory. This portion was considered to be representative of $<0.1 \mathrm{t}$. Frozen samples were finely ground (particle size $<100 \mu \mathrm{m}$ ) in a disk mill and were homogenized. Subsequently, $500 \mathrm{~g}$ portions were transferred to polyethylene containers with stoppers and stored in a freezer. Portions of 50 and $25 \mathrm{~g}$ were used for Se and aflatoxin determinations, in duplicates. For radioactivity analysis, incremental samples were taken from the bags and homogenized; final portions of $2 \mathrm{~kg}$ were obtained. Samples, incinerated according to the Association of Official Analytical Chemists (AOAC 2005), were properly packed (to fill a 2 $\mathrm{cm}$ tall container - about $50 \mathrm{~g}$ sample) in cylindrical plastic containers with a volume of $300 \mathrm{~mL}$. After packing, samples were sealed and remained at rest for a period of forty days to reach secular equilibrium. Measurements were performed at the Laboratory of Applied Nuclear Physics (Physics Department, State University of Londrina) (LFNA/UEL).

\section{Selenium determination}

The analysis of selenium was performed by ICP optical emission spectrometry (OES), using the atomic emission (28). The digestion of samples was carried out by acid in microwave in a closed system. Mass of about $0.3 \mathrm{~g}+3 \mathrm{~mL}$ of concentrated nitric acid and $1 \mathrm{~mL}$ of hydrogen peroxide, high pressure system 100 DAK Bergof, irradiation with 200 watts for five minutes and increase 50 watts $\min ^{-1}$ up to 700 watts for fifteen minutes, total time thirty minutes. It was then cooled, depressurized and swelled to $50 \mathrm{~mL}$. The limit of detection (LOD) was $1.50 \mathrm{mg} \mathrm{g}^{-1}$ and the limit of quantification (LOQ) was $3.00 \mathrm{mg} \mathrm{g}^{-1}$. The LOQ was defined as the lowest point of the curve with high reproducibility, axial view. The level of recovery was $90 \%(n=30)$. The analytical lines used for selenium determination was $196.03 \mathrm{~nm}$. The operational features of the spectrometer were: operating range optics - Used: 170 to $850 \mathrm{~nm}$, power radio frequency $=1300$ watts box, plasma gas flow rate $=15 \mathrm{~L} \mathrm{~min}^{-1}-$ adjunct $=2 \mathrm{~L} \mathrm{~min}^{-1}-0.6$ nebulizer $\mathrm{mL} \mathrm{min}^{-1}$, peristaltic pump with adjustable flow rate of $2 \mathrm{~mL} \mathrm{~min}^{-1}$.

\section{Aflatoxin Determination}

Aflatoxin determination was performed by liquid chromatography (LC) coupled with tandem - mass spectrometry (MS-MS) APCI in the positive detection mode (Xavier and Scussel 2008). The LC conditions (C8 column) involved a mobile-phase with a methanol/water gradient [ $45 \%$ water $/ 55 \%$ methanol (tree minutes); from three to five minutes the gradient was changed to $30 \%$ water $/ 70 \%$

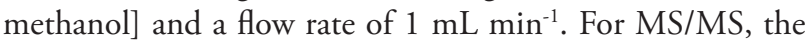
parent and two daughter ions $(\mathrm{m} / \mathrm{z})$ were selected for each toxin as follows: AFB1, $m / z$ 313.1 (241.10 and 285.10); AFB2, $m / z 315$ (259.09 and 287.20); AFG1, $m / z 329.1$ (200.05 and 243.05); and AFG2, m/z 331.2 (245.07 and 231.20). The LOD and LOQ values for LC-MS/MS of AFB1, AFB2, AFG1, AFG2 were 0.05, 0.075, 0.075 and 0.1 $\mu \mathrm{g} \mathrm{kg}^{-1}$ and $0.15,0.2,0.2$ and $0.3 \mu \mathrm{g} \mathrm{kg}^{-1}$ for each aflatoxin, respectively. The LOD and LOQ values for total aflatoxin were 0.3 and $0.85 \mu \mathrm{g} \mathrm{kg}^{-1}$. To obtain those parameters, the 
finely ground Brazil nuts were homogenized and spiked prior to extraction with aflatoxins at five concentrations between 1 to $10 \mu \mathrm{g} \mathrm{kg}^{-1}$. Portions of $25 \mathrm{~g}$ were taken for extraction by adding $100 \mathrm{~mL}$ of acetonitrile/water $(80: 20, \mathrm{v} / \mathrm{v})$ to the sample, which was followed by mixing for $2 \mathrm{~h}$ and filtration. The LOD method was defined by t times the signal-to noise ratio, and the LOQ method was defined by 6 times the signalto-noise ratio. Five-point analytical curves were constructed for quantification and for the estimation of LOD and LOQ. Each point corresponded to a mean of five injections of each extract. The recoveries for each aflatoxin (AFB1, AFB2, AFG1, AFG2) were $92.4,72.5,99.8$, and $97.1 \%$, respectively. The shell/nut ratio used for calculation was that reported by de Mello and Scussel (2007) [60:40 (60\% shell/40\% nut) with a factor of 1.5 , which was considered the standard ratio for normal healthy whole Brazil nuts].

\section{Radioactivity determination by Gamma-Ray Spectrometry}

Traces of the radionuclides ${ }^{228} \mathrm{Ra},{ }^{226} \mathrm{Ra}$ and ${ }^{224} \mathrm{Ra}$ were measured by gamma spectrometry using a HPGe detector (GEM-M 7080-PS, ORTEC) with 66\% relative efficiency. Each nut sample was counted for 86,400 seconds. The concentration of ${ }^{228} \mathrm{Ra}$ was determined from the 911,338 and $969 \mathrm{keV}$ lines for ${ }^{228} \mathrm{Ac}$ in each sample. The concentration of ${ }^{226} \mathrm{Ra}$ was determined from the 609, 1120 and 1764.5 $\mathrm{keV}$ lines for ${ }^{214} \mathrm{Bi}$, and from the 352 and $295 \mathrm{keV}$ lines for ${ }^{214} \mathrm{~Pb}$. The average activity of each of these two radionuclides in all samples was then calculated. Subsequently, an average weighted by the variances of these two values was used to determine the average value of the activity of ${ }^{226} \mathrm{Ra}$ and ${ }^{228} \mathrm{Ra}$ in these nuts. The concentration of ${ }^{224} \mathrm{Ra}$ was obtaind from the $239 \mathrm{keV}$ line for ${ }^{212} \mathrm{~Pb}$ and the $583 \mathrm{keV}$ line for ${ }^{208} \mathrm{Tl}$. The minimum detectable activity (MDA) for each spectral line is shown in Table 1.

Table 1 - Minimum Detectable Activity (AMD) for each energy line used in the determination of radionuclides.

\begin{tabular}{ccc}
\hline Radionuclides & Energy $(\mathrm{keV})$ & AMD $(\mathrm{Bq} / \mathrm{kg})$ \\
\hline \multirow{2}{*}{${ }^{214} \mathrm{Bi}^{\mathrm{a}}$} & 609.3 & 14.7 \\
& 1120 & 47.7 \\
& 1764 & 34.2 \\
\hline \multirow{2}{*}{${ }^{214} \mathrm{~Pb}^{\mathrm{b}}$} & 351.93 & 18.2 \\
& 295 & 32.4 \\
\hline \multirow{2}{*}{${ }^{228} \mathrm{AC}^{\mathrm{c}}$} & 338 & 57.2 \\
& 911.20 & 26.4 \\
\hline${ }^{208} \mathrm{~T}^{\mathrm{d}}$ & 969 & 49.1 \\
\hline${ }^{212} \mathrm{~Pb}^{\mathrm{b}}$ & 583 & 7.67 \\
\hline
\end{tabular}

\section{Committed effective doses}

The calculation of dose per unit intake is provided by the International Commission on Radiological Protection (ICRP 1996). The potential radiological impact through food intake is assessed from the calculation of committed effective dose (CED) in Sv.a-1, given by the equation: CED = e (g) ATc; where: $\mathrm{e}(\mathrm{g})$ is the committed effective dose per unit intake, or the effective dose coefficient, $\mathrm{A}$ is the average activity of the radionuclide and $\mathrm{T}_{\mathrm{c}}$ is the rate of annual consumption of that food. The values for the coefficient of effective dose $[\mathrm{e}(\mathrm{g})]$ are based on models and metabolic data used for the evaluation by the United Nations Scientific Committee on the Effects of Atomic Radiation (UNSCEAR 2000). These coefficients of effective dose of interest for this work are those defined by the International Atomic Energy Agency (IAEA 1996). The values of the rate of annual consumption ( $\mathrm{Tc}$ ) of nuts for Brazil used in this study were suggested by the Household Budget Survey (POF) from the Brazilian Institute of Geography and Statistics (IBGE 2004) and also suggested by diet Cluster GEMs / Food (Global Environmental Monitoring System) (WHO 2006).

\section{Statistical analysis}

Comparison between the sizes was performed using analysis of variance (ANOVA). For correlation analysis, we used the Pearson coefficient. The Student t-test and chi-square test were used for comparison between doses and committed ceiling.

\section{RESULTS AND DISCUSSION}

\section{Selenium in Brazil nut}

Selenium levels ranged from 9.4 to $39.0 \mu \mathrm{g} \mathrm{g}^{-1}$, see Table 2. There were no significant differences in Se concentration ( $p>0.18$ ) among the different sizes of nuts. Moodley et al. (2007) studied the concentration of Se in different types of tree nuts sold in South Africa and reported a concentration of $36.1 \pm 0.4 \mu \mathrm{g} \mathrm{g}^{-1}$ in Brazil nuts, and $0.0039 \pm 0.0007$

Table 2 - Selenium concentration in the Brazil nut shelled the different sizes of the 2009 harvest.

\begin{tabular}{|c|c|c|c|}
\hline \multirow[b]{2}{*}{ Brazil nut Size } & \multicolumn{3}{|c|}{ Selenium $^{\mathrm{a}}(\mu \mathrm{g} / \mathrm{g})$} \\
\hline & Mean ${ }^{b}$ & Range & $\mathrm{RSD}^{\mathrm{c}}(\%)$ \\
\hline Small & 24.2 & $17.0-39.0$ & 7.3 \\
\hline Medium & 24.7 & $16.0-37.0$ & 7.6 \\
\hline Large & 19.2 & $9.4-27.0$ & 6.5 \\
\hline Mean & 22.7 & $9.4-39.0$ & 7.4 \\
\hline P-value ${ }^{d}$ & & $0.19^{\mathrm{e}}$ & \\
\hline
\end{tabular}

Note: ${ }^{\mathrm{L} O \mathrm{OQ}}=3,00 \mu \mathrm{g} / \mathrm{g}$. ${ }^{\mathrm{b}}$ Mean selenium concentration. ${ }^{\mathrm{c}}$ Relative standard deviation. ${ }^{\mathrm{d}} \mathrm{p}<0,05$ indicates significant difference. ${ }^{\mathrm{e}} \mathrm{P}$-value obtained by Fisher test. 
$\mu \mathrm{g} \mathrm{g}^{-1}$ in almonds, but did not detect levels of Se in other types of nuts studied. Rodushkin et al. (2008) reported a wide variation in Se levels among different types of nuts and reported a relatively low concentration in shelled Brazil nuts $\left(1.2 \mu \mathrm{g} \mathrm{g}^{-1}\right)$. The levels of Se found in this study were lower than those reported $\left(126 \mu \mathrm{g} \mathrm{g}^{-1}\right)$ by Chunhieng et al. (2004). However, our results were similar to those reported by Parekh et al. (2008) who reported that levels of Se were inversely proportional to the concentration of barium in the samples studied. The concentration of Se in Brazil nuts seems to be influenced by the absorption capacity of the tree and may vary according to factors arising from the composition of the soil from which they originate. Levels of 8.0 to $69.7 \mu \mathrm{g} \mathrm{g}^{-1}$ in shelled Brazil nuts from different regions of the Amazon have been reported by Pacheco and Scussel (2007). In that study, the authors found also a correlation between levels of Se and aflatoxin: the higher the level of $\mathrm{Se}$, the higher the aflatoxin contamination. Considering the fact that their correlation, as well as the levels obtained in our study is significantly lower than those reported by Pacheco and Scussel (2007), it may be possible to explain the non-detection of aflatoxins in our samples studied by the LOQ.

Although Se is a fundamental element that is prized for its antioxidant activity, it is also investigated due to the ambiguity of its actions because both beneficial and toxic effects on organisms have been observed. Its therapeutic range is considered narrow, and its toxicity is partly related to the ability of some compounds containing Se to generate free radicals: therefore, the intake of such compounds should be monitored. The Recommended Dietary Allowance (RDA) for Se is $55 \mu \mathrm{g} \mathrm{day}{ }^{-1}$ for adults (NAS 2000), which is based on the amount needed to maximize the synthesis of the selenoprotein glutathione peroxidase (GPx), measured by the plateau in the activity of the plasma isoform of this enzyme. The Tolerable Upper Intake Level (UL) for adults is $400 \mu \mathrm{g}$ day $^{-1}$ based on selenosis, which is the adverse effect resulting from excess intake (NAS 2000). Studies report that consumption of 300 $\mu \mathrm{g}$ day $^{-1}$ of Se can have toxic effects on both growth hormone and thyroid hormone synthesis (Kaprara and Krassas 2006).
According to Thomson et al. 2008, the consumption of two nuts (mean $100 \mu \mathrm{g} \mathrm{day}^{-1}$ ) would be sufficient to obtain the effects of antioxidants in the body. According to that study, the consumption of peeled Brazil nuts of medium size with an edible portion equal to $4.6 \mathrm{~g}$ (De Mello and Scussel 2007) provides a concentration of Se in the range of 43.2 to 179.4 $\mu \mathrm{g} \mathrm{g}^{-1}$, which covers both the RDA and UL.

\section{Aflatoxins in Brazil nuts}

Despite the good sensitivity of the LC-MS/MS method $\left(\mathrm{LOQ}=0.85 \mu \mathrm{g} \mathrm{kg}^{-1} \Sigma \mathrm{AFL}\right)$, aflatoxins were not detected in any sample. One explanation may be that the stripped Brazil nuts underwent three rounds of sorting/screening during processing (Pacheco and Scussel 2009). These steps allow for the disposal of damaged nuts that do not conform to processing standards, greatly reducing the possibility of contamination of batches of the product. Pacheco et al. (2010) reported that samples obtained after drying (i.e., collected at the end of the process) were not contaminated by aflatoxins. Other researchers have reported no detection of aflatoxins in shelled Brazil nuts (Souza and Menezes 2004; IoannouKakouri et al. 1999). According to the report of the Codex Alimentarius Commission (CAC 2010), a change in the limit of aflatoxins from $4 \mu \mathrm{g} \mathrm{kg}^{-1}$ to $10 \mu \mathrm{g} \mathrm{kg}^{-1}$ in shelled Brazil nuts for consumption was recently established, and this limit was further changed to $15 \mu \mathrm{g} \mathrm{kg}^{-1}$ for shelled nuts destined for further processing. Therefore, the samples studied in this work were in accordance with Brazilian law, with a maximum of $30 \mu \mathrm{gg}^{-1}$ (Brazil 1976) and also met European legislation standards.

\section{${ }^{226} \mathrm{Ra},{ }^{228} \mathrm{Ra}$ and ${ }^{224} \mathrm{Ra}$ in Brazil nuts}

Activities measured for each radionuclide are summarized in Table 3. All samples studied showed activity above the minimum detectable activities for all spectral lines used. The activity of ${ }^{226} \mathrm{Ra}$ was calculated from the weighted average of the activities of the radionuclides ${ }^{214} \mathrm{~Pb}$ and ${ }^{214} \mathrm{Bi}$. This was done because ${ }^{226} \mathrm{Ra}$, which has a half life of 1620 years, is actually present in Brazil nuts, as was ${ }^{238} \mathrm{U}$, which has a half life of $4.5 \times 10^{9}$ years. However there is a possibility of the nut seeds

Table 3 - Activity of radionuclides in the Brazil nut shelled the different sizes of the 2009 harvest.

\begin{tabular}{|c|c|c|c|c|c|c|c|c|c|}
\hline \multirow[b]{2}{*}{ Brazil nut Size } & \multicolumn{3}{|c|}{${ }^{224} \mathrm{Ra}^{\mathrm{a}}(\mathrm{Bq} / \mathrm{kg})$} & \multicolumn{3}{|c|}{${ }^{226} \mathrm{Ra}(\mathrm{Bq} / \mathrm{kg})$} & \multicolumn{3}{|c|}{${ }^{228} \mathrm{Ra}^{\mathrm{a}}(\mathrm{Bq} / \mathrm{kg})$} \\
\hline & Mean $^{b}$ & Range & $\mathrm{RSD}^{\mathrm{c}}(\%)$ & Mean $^{b}$ & Range & $\left.\mathrm{RSD}^{\mathrm{c}} \%\right)$ & Mean $^{b}$ & Range & $\operatorname{RSD}^{\mathrm{c}}(\%)$ \\
\hline Small & $18.1^{d}$ & $11.9-21.8$ & 3.8 & 111.1 & $78.6-134.5$ & 19.5 & $113.5^{d}$ & $82.8-136.1$ & 19.1 \\
\hline Medium & $13.7^{\mathrm{e}}$ & $11.2-17.1$ & 2.0 & 103.9 & $87.5-129.4$ & 14.1 & $93.6^{\mathrm{d}, \mathrm{e}}$ & $84.1-112.8$ & 9.2 \\
\hline Large & $15.5^{\mathrm{d}, \mathrm{e}}$ & $12.2-18.0$ & 1.7 & 99.4 & $93.2-107.0$ & 4.3 & $91.3^{\mathrm{e}}$ & $81.6-106.4$ & 7.8 \\
\hline Mean & 15.8 & $11.2-21.8$ & 3.2 & 104.8 & $78.7-134.5$ & 14.5 & 99.5 & $81.7-136.1$ & 16.1 \\
\hline$P$ - value ${ }^{f}$ & \multicolumn{3}{|c|}{$0.01^{9}$} & \multicolumn{3}{|c|}{$0.30^{9}$} & \multicolumn{3}{|c|}{$0.01^{g}$} \\
\hline
\end{tabular}

Note: a Parameters in the ANOVA rejected the null hypothesis. ${ }^{\mathrm{b}}$ Mean activity of ${ }^{224} \mathrm{Ra},{ }^{226} \mathrm{Ra}$ and ${ }^{228} \mathrm{Ra}$. c Relative standard deviation. ${ }^{\mathrm{de} e}$ Different letters represent means with significant differences $(p<0,05) .{ }^{\dagger} p<0,05$ indicates significant difference. ${ }^{i} P$-value obtained by Kruskal-Wallis test. 
to absorbing ${ }^{226} \mathrm{Ra}$ instead of ${ }^{238} \mathrm{U}$; therefore, we attributed the activities of ${ }^{214} \mathrm{~Pb}$ and ${ }^{214} \mathrm{Bi}$ to ${ }^{226} \mathrm{Ra}$. In the same way, the activity of ${ }^{228} \mathrm{Ac}$ was attributed to ${ }^{228} \mathrm{Ra}$, and the activities of ${ }^{212} \mathrm{~Pb}$ and ${ }^{208} \mathrm{Tl}$ were attributed to ${ }^{224} \mathrm{Ra}$.

High values for the activities of both ${ }^{226} \mathrm{Ra}$ and ${ }^{228} \mathrm{Ra}$ in nuts, compared to other foods, were expected (Anderson and Cunningham 2005; Scheibel and Appoloni 2007), because the nut trees from Brazil have a great capacity to absorb radioisotopes from the soil. It is well known that the Brazil nut tree has a high capacity for barium uptake from soil (Hiromoto et al. 1996). Taking into account the similarity of the chemical behaviour of barium and radium, this propertie explains the capacity for radioisotopes absorption.

The low activity concentrations found for ${ }^{224} \mathrm{Ra}$ agree with the values reported by Parekh et al. (2008). The lowest activity was observed for ${ }^{224} \mathrm{Ra}\left(11.21 \pm 3.18 \mathrm{~Bq} \mathrm{~kg}^{-1}\right)$ and the highest was found for ${ }^{228} \mathrm{Ra}\left(136.10 \pm 16.15 \mathrm{~Bq} \mathrm{~kg}^{-1}\right)$.

The values of activities for ${ }^{226} \mathrm{Ra}$ and ${ }^{228} \mathrm{Ra}$ were higher than those reported by Parekh et al. (2008) and by Hiromoto et al. (1996). Adopting a significance level of $\alpha=0.05$, there are no differences in the activity of ${ }^{226} \mathrm{Ra}(\mathrm{p}>0.30)$ among the different sizes of nuts. However, for ${ }^{224} \mathrm{Ra}$ and ${ }^{228} \mathrm{Ra}$, a similar test showed statistically significant differences between different sizes. In subsequent tests for multiple comparisons with the average of the ranks, increased activity of ${ }^{224} \mathrm{Ra}$ was detected for small and large nuts. For ${ }^{228} \mathrm{Ra}$, the highest activities occurred in small and medium nuts. There may be a pattern of decreased activity of radionuclides with increasing nut size.

Finally, we evaluated the possible relationship between Se concentration and the activity of ${ }^{224} \mathrm{Ra},{ }^{226} \mathrm{Ra}$ and ${ }^{228} \mathrm{Ra}$ (Figure 2); however, the correlation coefficients were below $50 \%$, allowing us to conclude that there was no relationship in the studied samples, and that the correlation was strongest among radionuclides (Figure 3 ).

The committed effective doses (CED) were calculated and are presented in Table 4. The CEDs, estimated from the rates of consumption, suggested significant differences between the three radionuclides $(p<0.001)$. However, based on the results of Table 3 , it can be stated that for both estimates of consumption, all CEDs observed in this study show doses below the maximum established by the UNSCEAR (2000) for the radionuclides studied; therefore, no health risk is involved.

The results of this study of radionuclide activity and Se concentration in Brazil nuts can be useful for our understanding of the process of element's absorption by these nuts. Further analysis could provide information on soil characteristics of the region of origin. Another suggestion for future work would be the activity determination of radionuclides of the uranium series which are before ${ }^{226} \mathrm{Ra}$,
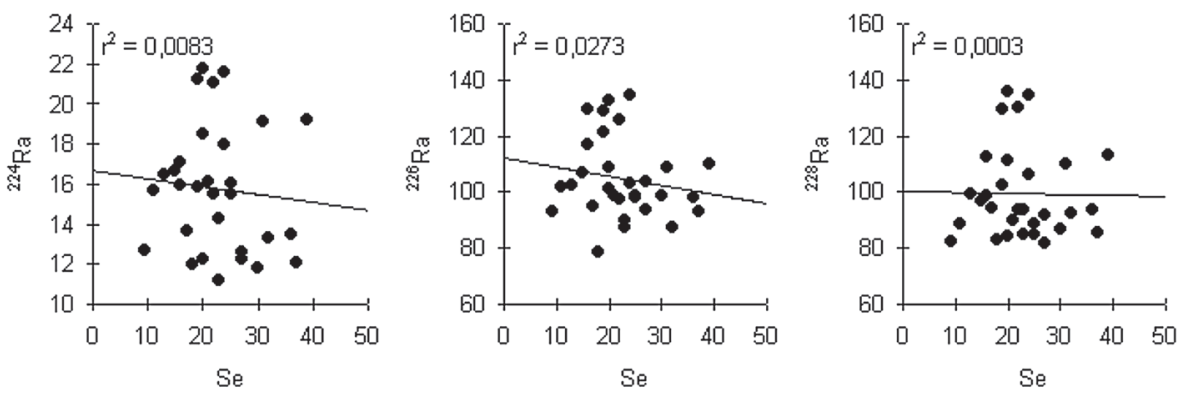

Figure 2 - Correlation between Se and radionuclides: ${ }^{224} \mathrm{Ra},{ }^{226} \mathrm{Ra}$ and ${ }^{228} \mathrm{Ra}$.
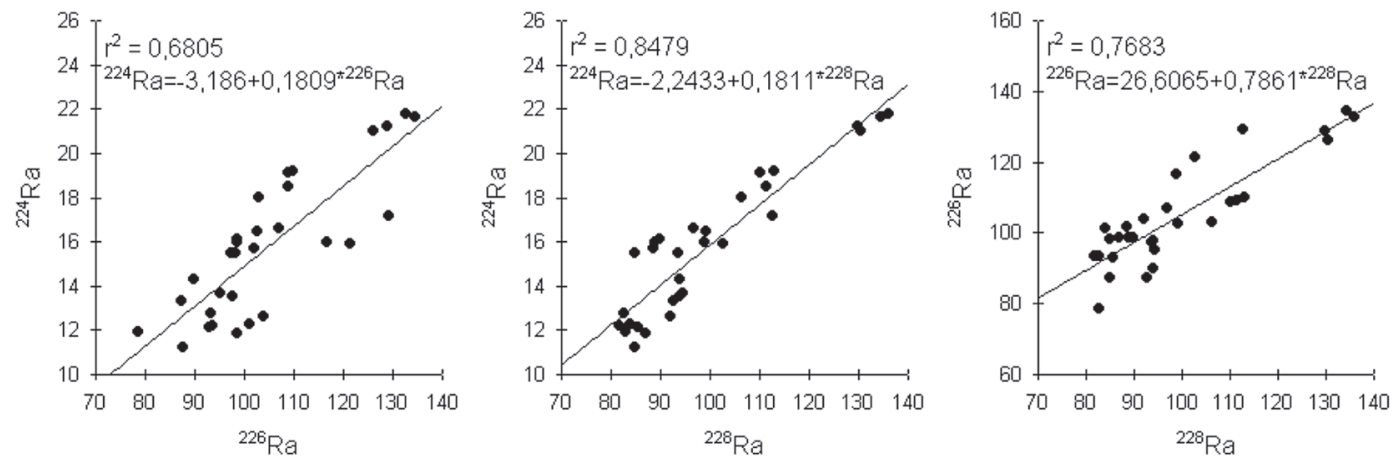

Figure 3 - Correlation between radionuclides: ${ }^{224} \mathrm{Ra},{ }^{226} \mathrm{Ra}$ and $228 \mathrm{Ra}$. 
Table 4 - Comparison of the committed effective dose (CED) for ${ }^{224} \mathrm{Ra},{ }^{226} \mathrm{Ra}$ and ${ }^{228} \mathrm{Ra}$ in shelled Brazil nuts based on different rates of annual consumption.

\begin{tabular}{|c|c|c|c|c|c|c|c|}
\hline \multirow{2}{*}{ Radionuclides } & \multirow{2}{*}{ CED (Sv.a-1)c } & \multicolumn{3}{|c|}{$\mathrm{IBGE}^{\mathrm{a}}$} & \multicolumn{3}{|c|}{$\mathrm{WHO}$} \\
\hline & & d & Range $^{e}$ & $\mathrm{P}^{\mathrm{f}}$ & $d$ & Range $^{e}$ & $\mathrm{P}^{f}$ \\
\hline${ }^{224} \mathrm{Ra}$ & 0.22 & $0.06 \pm 0.01$ & $0.04-0.08$ & $<0.0001$ & $0.05 \pm 0.01$ & $0.03-0.06$ & $<0.0001$ \\
\hline${ }^{226} \mathrm{Ra}$ & 6.3 & $1.50 \pm 0.21$ & $1.12-1.92$ & $<0.0001$ & $1.07 \pm 0.15$ & $0.80-1.37$ & $<0.0001$ \\
\hline${ }^{228} \mathrm{Ra}$ & 11.0 & $3.50 \pm 0.57$ & $2.87-4.79$ & $<0.0001$ & $2.51 \pm 0.41$ & $2.06-3.43$ & $<0.0001$ \\
\hline
\end{tabular}

Note: annual consumption rates as the Brazilian Institute of Geography and Statistic. ${ }^{\mathrm{b}}$ Rates of annual consumption as World Health Organization. ${ }^{\mathrm{c}}$ Maximum committed effective dose by intake established by UNSCEAR (2000). ' Mean committed effective dose \pm standard deviation.

so that we could make an analogy between the activities of these two radionuclides $\left({ }^{238} \mathrm{U}\right.$ and $\left.{ }^{226} \mathrm{Ra}\right)$. This would also give an idea about the process of absorbing elements from soil by Brazil nut tree.

Thus, it would be possible to make an analysis of the whole series of radionuclides to see whether it is in radioactive equilibrium in Brazil nut. In regard to other variables in the production of aflatoxins, it would be interesting to assess the moisture content and water activity of Brazil nuts throughout the entire production chain. The results of such an investigation could contribute to the search for tools to prevent contamination.

\section{CONCLUSIONS}

The selenium mean concentration was $22.7 \pm 7.4$. Mean activities determined for the following radium isotopes were: $15.77 \mathrm{~Bq} \mathrm{~kg}^{-1}$ for ${ }^{224} \mathrm{Ra}, 104.8 \mathrm{~Bq} \mathrm{~kg}^{-1}$ for ${ }^{226} \mathrm{Ra}$ and $99.48 \mathrm{~Bq} \mathrm{~kg}^{-1}$ for ${ }^{228} \mathrm{Ra}$. We did not find aflatoxins above the quantification limit. Based on the results, it can be stated that for both estimates of consumption, all CEDs observed in this study show doses below the maximum established by the UNSCEAR (2000) for the radionuclides studied; therefore, no health risk is involved in the Brazil nut consumption according to the evaluated samples.

\section{ACKNOWLEDGMENTS}

We are grateful to the Research Foundation of the State of Amazonas - FAPEAM for financial support; to the Coordination of Development of Higher Education - CAPES for the research fellowship; and to Mrs. Viviane Scheibel de Almeida, of the Federal University of Mato Grosso of the South, for information about the committed effective doses.

\section{REFERENCES}

Anderson, D.L.; Cunningham, W.C. 2005. Analysis of total diet study foods for gamma-ray emitting radionuclides. Journal of Radioanalytical and Nuclear Chemistry, 264 (2): 371-376.

Association of Official Analytical Chemists (AOAC). 2005. Official methods of analysis of the 18th international AOAC, Horwitz, W., Latimer, G. W., Jr., Eds.; AOAC: Gaithersburg, MD.
Brazil. Ministry of Agriculture. 1976. Brazil-nut: a preliminary survey. Belém: Police State of the Ministry of Agriculture. Federation of Agriculture of the State of Pará. 69pp.

Brazilian Institute of Geography and Statistics (IBGE). 2004. Expenditure Survey - Household Food Acquisition Per Capta (2002-2003).

Celik, N.; Cevik, U.; Celik, A.; Kucukomeroglu, B. 2008. Determination of indoor radon and soil radioactivity levels in Giresin, Turkey. Journal of Environmental Radioactivity, 99(8): 1349-1354.

Chunhieng, T., Hafidi, A., Pioch, D., Brochier, J.; Montet, D. 2008. Detailed study of Brazil nut (Bertholletia excelsa) oil microcompounds: phospholipids, tocopherols and sterols. Journal of the Brazilian Chemical Society, 19 (7): 1374-1380.

Chunhieng, T., Pétritis, K., Elfakir, C., Brochier, J., Goli, T.; Montet, D. 2004. Study of selenium in the protein fractions of the Brazil nut, Bertholletia excelsa. Journal of Agricultural and Food Chemistry, 52: 4318-4322.

Codex Alimentarius Commission (CAC 2010). Report of the Fourth Session of the Codex Committee on Contaminants in Foods. CL 2010/13-CF. Izmir, Turkey. 2010.

De Mello, F.R.; Scussel, V.M. 2007. Characteristics of in-shell Brazil nuts and their relationship to aflatoxin contamination: criteria for sorting. Journal of Agricultural and Food Chemistry, 55: 9305-9310.

European Union 2003. Commission Decision of 4 July 2003, imposing special conditions on the import of Brazil nuts in shell originating in or consigned from Brazil (2003/493/EC). Official Journal of the European Union. 2003, 5.7.2003, L 168/33.

Gabay, J.; Sax, J.J. 1969. Retention of radium due to ingestion of Brazil nuts. Health Physical. Pergamon Press. 16: 812-813.

Hiromoto, G., Oliveira, J., Carvalho, J.S., Vicente, R.; Bellintani, S.A. 1996. Collective dose and risk assessment from Brazil nut consumption. Radiation Protection Dosimetry, 67 (3): 229-230.

Irigaray, P.; Mewby, J.A.; Clapp, R.; Hardell, L.; Howard, V.; Montagnier, L.; Epstein, S.; Belpomme, D. 2007. Lifestylerelated factors and environmental agents causing cancer: an overview. Biomedicine \& Pharmacotherapy, 61(10): 640-658.

International Agency of Research on Cancer (IARC). 1997. Evaluation of carcinogenic risks to humans: some naturally occurring substances: aromatic amines and mycotoxins. Lyon. (IARC Monographs, 56). 245-395. 
International Atomic Energy Agency (IAEA). 1996. International Basic Safety Standards for Protection against Ionizing Radiation and for the Safety of Radiation Sources. Safety series N 115.

International Commission on Radiological Protection (ICRP). 1996. Age-dependent doses to members of the public from intake of radionuclides: Part 5 - Compilation of Ingestion \& Inhalation Dose coefficients. ICRP Publication 72. Pergamon Press, Oxford.

Ioannou-Kakouri E., Aletrari M., Christou E., Hadjioannou-Ralli A., Koliou A.; Akkelidou D. 1999. Surveillance and control of aflatoxins B1, B2, G1, G2 and M1 foodstuffs in the Republic of Cyprus:1992-1996. Food Chemical Contaminants, 82 (4): 883-892.

Johnsson, P., Lindblad, M., Thim, A.M., Jonsson, N., Vargas, E.A., Medeiros, N.L., Brabet, C., De Araújo, M.Q.; Olsen, M. 2008. Growth of aflatoxigenic moulds and aflatoxin formation in Brazil nuts. World Mycotoxin Journal, 1(2): 127-137.

Kaprara A.; Krassas G.E. 2006. Selenium and thyroidal function; the role of immunoassays. Hellenic Journal of Nuclear Medicine, 9 (3): 195-203.

Ministry of Industry and Commerce Development (MICD). 2010. Department of Foreign Trade. System for Analysis of Foreign Trade Information via Internet (ALICEWEB). (http://aliceweb. desenvolvimento.gov.br/) (Accessed 10/05/2010.

Moodley, R., Andrew, K.; Jonnalagadda, S.B. 2007. Elemental composition and chemical characteristics of five edible nuts (almond, Brazil, pecan, macadamia and walnut) consumed in Southern Africa, Journal of Environmental Science and Health. Part B, 42 (5): 585 - 591.

National Academy of Sciences (NAS). 2000. Dietary reference intakes for vitamin C, vitamin E, selenium and carotenoids. (http:// www.nap.edu/catalog/9810.html). Accessed 13/05/2010).

Pacheco, A.M.; Scussel, V.M. 2007. Selenium and aflatoxin levels in raw Brazil nuts from the Easten and Western Amazon basin. Journal of Agricultural and Food Chemistry, 55 (26): $11087-$ 11092.

Pacheco, A.M.; Scussel, V.M. 2009. Aflatoxins evaluation on inshell and shelled dry Brazil nuts for export analyzed by LC-MS/ MS - 2006 and 2007 harvests. World Mycotoxin Journal, 2 (3): 295-304.

Pacheco, A.M.; Lucas, A.; Parente, R.; Pacheco, N. 2010. Association between aflatoxin and aflatoxigenic fungi in Brazil nut (Bertholletia excelsa H.B.K.). Brazilian Journal of Food Science and Technology, 30 (22): 1-6.

Parekh, P.P., Khan, A.R., Torres, M.A.; Kitto, M.E. 2008. Concentrations of selenium, barium, and radium in Brazil nuts. Journal of Food Composition and Analysis, 21: 332-335.
Rayman, M.P. 2000. The importance of selenium to human health. The Lancet. 356(9225): 233-241.

Ryan, E., Galvin, K., O’Connor, T.P., Maguire, A.R.; O’Brien, N. M. 2006. Fatty acid profile, tocopherol, squalene and phytosterol content of Brazil, pecan, pine, pistachio and cashew nuts. Int. Journal of Food Science and Nutrition, 57: 219-228.

Rodushkin, B., Engström, E., Sörlin, D.; Baxter, D. 2008. Levels of inorganic constituents in raw nuts and seeds on the Swedish market. Science of the Total Environment, 392: 290-304.

Scheibel, V;; Appoloni, C.R. 2007. Radioactive trace measurements of some exported foods from the South of Brazil. Journal of Food Composition and Analysis, 20: 650-653.

Smith, K.A. 1971. The comparative uptake and translocation by plants of calcium, strontium, barium, and radium. Plant Soil, 34: 369-379.

Souza, M.L.; Menezes, H.C. 2004. Processing of Brazil nut and meal and cassava flour: quality parameters. Brazilian Journal of Food Science and Technology, 24 (1): 120-128.

Scussel, V.M. 2004. Aflatoxin and food safety: recent South American perspectives. Journal of Toxicology, Toxin Reviews, 23: 179-216.

Tagami, K., Uchida, S. 2009. Radium-226 transfer factor from soils to crops and its simple estimation method using uranium and barium concentrations. Chemosphere, 77(2009): 105-114.

Thomson, C.D., Chisholm, A., McLachlan, S.K.; Campbell, J.M. 2008. Brazil Nuts: an effective way to improve selenium. American Journal of Clinical Nutrition, 87: 379-384.

Turner, R.C.; Radley, J.M.; Mayneord, W.V. 1958. The naturally occurring alpha activity of foods. Health Physical. 1: 268-275.

United Nations Scientific Committee on the Effects of Atomic Radiation (UNSCEAR), 2000. Sources and Effects of Ionizing Radiation. Report Vol. I. United Nations, New York.

United States Environmental Protection Agency (US EPA), 1996. Inductively coupled plasma-atomic emission spectrometry. SW846 test methods for evaluating solid wastes physical/chemical methods, method 6010B.

Xavier, J.J.M.; Scussel, V.M. 2008. Development of an LC-MS/MS method for the determination of aflatoxins B1, B2, G1, and G2 in Brazil nut. International of Journal Environmental Analytical Chemistry, 88(6): 425-433.

World Health Organization (WHO), 2006. GEMS/Food Consumption Cluster Diets. (http://www.who.int/foodsafety/ publications/chem/regional_diets/en/). Accessed 26/04/2010).

Yang, J. 2009. Brazil nuts and associated health benefits: A review. Food Science and Technology, 42: 1573-1580.

Recebido em 26/11/2010

Aceito em 27/03/2011 